\title{
IDENTIFIKASI DAN KARAKTERISASI 11 KULTIVAR TANAMAN TOMAT SEBAGAI SUMBER GENETIK UNTUK PERSILANGAN
}

\author{
Identification and Characterization 11 Tomato Cultivars \\ as Genetic Sources for Breeding
}

\author{
Muhammad Abdillah Hasan Qonit ${ }^{1}$, Kusumiyati², dan Syariful Mubarok ${ }^{*}, 2$ \\ ${ }^{1}$ Mahasiswa Program Studi Agroteknologi, Fakultas Pertanian, Universitas Padjadjaran, \\ ${ }^{2}$ Staf Pengajar Departemen Budidaya Pertanian, Fakultas Pertanian, Universitas Padjadjaran \\ Jl. Raya Bandung - Sumedang km 21, Jatinangor
}

*Alamat Korespondensi: syariful.mubarok@unpad.ac.id

\begin{abstract}
ABSTRAK
Salah satu jenis tanaman hortikultura penting yang banyak dikembangkan di Indonesia adalah tanaman tomat (Lycopersicum esculentum Mill). Beberapa cara dapat dilakukan untuk meningkatkan produksi dan kualitas tanaman yang salah satunya adalah dengan mendapatkan varietas unggul baru. Pada tahapan ini maka perlu diseleksi terlebih dahulu jenis tomat yang mempunyai hasil baik dan toleran terhadap gangguan organisme penggangu tanaman (OPT). Tujuan penelitian ini adalah untuk mendapatkan kultivar tomat yang baik dari segi pertumbuhan yang dapat dijadikan sebagai sumber genetik untuk bahan persilangan. Dalam percobaan ini dilakukan identifikasi dan karakterisasi 11 kultivar tomat hasil introduksi yang terdiri dari A: 'Oxheart'; B: 'Moskvich'; C: 'Valencia'; D: 'Marmande'; E: 'Moneymaker'; F: 'La Sweetie'; G: 'Principle Borghese'; H: 'Golden Sunrise'; I: 'Red Cherry'; J: 'Black Cherry'; dan K: 'Golden Jubille'. Hasil pengamatanam menunjukkan bahwa setiap kultivar tomat introduksi mempunyai respon pertumbuhan yang berbeda. Tomat 'Black Cherry' menunjukan respon pertumbuhan yang terbaik dengan pertimbangan tinggi tanaman, tinggi tandan pertama, diameter batang tanaman, jumlah bunga per tandan, dan jumlah buah per tandan.Serta mempunyai ketahanan terhadap serangan organisme pengganggu.
\end{abstract}

Kata kunci: introduksi, pertumbuhan, tomat

\begin{abstract}
One of the important horticultural crops in Indonensia is Tomato (Lycopersicum esculentum Mill.). Several methods can be used to improve productivity and quality of tomato such as by generating new tomato cultivar with desired characters. To generate new cultivars therefore new selection in parental tomato is needed to get the potential parental tomato as genetic background. The purpose of this study was to find out the potential tomato cultivars such as high productivity and quality, adaptive grown in Indonesia and also resistant to pest and disease. Eleven tomato cultivars introduction was used in this experiment consisted of A: 'Oxheart'; B: 'Moskvich'; C: 'Valencia'; D: 'Marmande'; E: 'Moneymaker'; F: 'La Sweetie'; G: 'Principle Borghese'; H: 'Golden Sunrise'; I: 'Red Cherry'; J: 'Black Cherry'; and K: 'Golden Jubille'. The results showed that each introduced tomato cultivar has a different response to environmental condition. Tomato 'Black Cherry' showed the best plant growth compared to other cultivars. It had the highest plant height; shoot diameter, no of flower per truss, and no of fruit per truss. It also showed as a resistant cultivar to the pest and disease.
\end{abstract}

Keywords: introduction, plant growth, tomato

\section{PENDAHULUAN}

Tomat (Lycopersicum esculentum

Mill) merupakan salah satu tanaman solanaceae yang berasal dari negara Amerika, terutama daerah Amerika Utara dan Selatan yang cukup diminati oleh masyarakat. Buah tanaman ini memiliki banyak manfaat karena kandungan gizi yang cukup kaya nutrisi seperti vitamin A, B, C, dan E, phytosterol, folic acid, antioksidan, lycopene, alpha dan beta karoten, serta potassium (Bhowmilk et al., 
2012). Menurut Pudjatmoko (2008) dalam Marliah, dkk. (2012) dalam setiap $100 \mathrm{~g}$ buah tomat mengandung 4,2 g karbohidrat, 0,3 g lemak, $1 \mathrm{~g}$ protein, $5 \mathrm{mg}$ kalsium, 27 $\mathrm{mg}$ fosfor, 0,5 $\mathrm{mg}$ zat besi, $1500 \mathrm{Si}$ vitamin A (karoten), $60 \mathrm{mg}$ vitamin B (tiamin), dan $40 \mathrm{mg}$ vitamin C. Selain gizi yang terkandung dalam buah, tomat pun mempunyai rasa enak yang dipengaruhi oleh kandungan gula, asam organik dan asam amino (Mubarok et al., 2016). Mengonsumsi buah tomat dalam bentuk olahan jus dapat mencegah fotoaging akibat iradiasi sinar ultraviolet-B (Wahyono $d k k$., 2011).

Berdasarkan data Badan Pusat Statistik (2016), produksi buah tomat di Indonesia pada tahun 2014 adalah 915,987 ton, lalu pada tahun 2015 terjadi penurunan menjadi 887,792 ton. Rendahnya produksi tomat di Indonesia disebabkan oleh keterbatasan varietas unggul yang mampu tumbuh dengan baik serta produksi dan kualitas yang tinggi di dataran rendah. Kemampuan berproduksi pada tanaman tomat bergantung pada interaksi antara pertumbuhan tanaman dan kondisi lingkungan pada saat penanaman seperti suhu, kelembaban relatif dan intensitas cahaya. Salah satu cara yang dapat ditempuh untuk mengingkatkan produktivitas dan kualitas tomat yaitu dengan menghasilkannya jenis kultivar tomat baru. Sehingga perlu dicara jenis tomat baru yang dijadikan sebagai sumber genetik untuk persilangan yang mempunyai karakter unggul dan dapat dikembangkan di Indonesia. Balai penelitian dan Pengembangan Pertanian telah melepas kultivar tanaman tomat yang mampu tumbuh di dataran rendah seperti kultivar Ratna, Berlian, dan Mutiara. Akan tetapi, varietas tersebut tidak mampu untuk menghasilkan buah tomat dengan kuantitas dan kualitas yang unggul (Wijayani dan Widodo, 2005). Oleh karena itu diperlukan usaha introduksi tanaman yang merupakan salah satu upaya untuk meningkatkan produksi dan kualitas tomat di Indonesia.

Introduksi tanaman adalah suatu kegiatan memasukan tanaman yang berasal dari luar daerah ke suatu daerah lain. Tujuan dilakukannya introduksi tanaman adalah untuk mendapatkan tanaman atau kultivar baru yang berasal dari luar daerah yang telah melalui tahap seleksi dan adaptasi. Tingkat keberhasilan dalam usaha introduksi tanaman dipengaruhi oleh keadaan suatu lingkungan penanaman dan tingkat kesesuaian tanaman terhadap lingkungan tersebut (Acquaah, 2007). Introduksi tanaman, diharapkan dapat memperoleh kultivar unggul dengan kriteria daya hasil tinggi, kualitas buah baik, ketahanan OPT yang baik di lingkungan setempat (Yusdar $d k k ., 1992$; Nukita dan Suwandi, 1992; Nazirwan dkk., 2014). Tujuan dari penelitian ini adalah untuk 
mendapatkan kultivar tomat yang pertumbuhannya baik untuk dijadikan sebagai sumber genetik untuk bahan persilangan. Hipotesis dari penlitian ini yakni terdapat kultivar tanaman tomat introduksi yang memiliki daya tumbuh tinggi di dataran rendah - medium dan dapat dijadikan sebagai tetua persilangan.

\section{METODE PENELITIAN}

Percobaan dilaksakan di dalam rumah plastik pada Desember 2016 hingga Februari 2017, bertempat di Laboratorium Kultur Terkendali (Hidroponik), Fakultas Pertanian, Universitas Padjadjaran, Jatinangor dengan ketinggian tempat sekitar $720 \mathrm{~m}$ di atas permukaan laut (dpl).

Rancangan percobaan yang akan digunakan adalah Rancangan Acak Kelompok (RAK) dengan ulangan sebanyak tiga kali ulangan. Kultivar tomat yang digunakan terdiri dari 11 kultivar, yaitu A: 'Oxheart'; B: 'Moskvich'; C: 'Valencia'; D: 'Marmande'; E: 'Moneymaker'; F: 'La Sweetie'; G: 'Principle Borghese'; H: 'Golden Sunrise'; I: 'Red Cherry'; J: 'Black Cherry'; dan K: 'Golden Jubille'.

Penanaman dilakukan di dalam polybag berdiameter $20 \mathrm{~cm}$ dan tinggi 30 cm. Media yang digunakan berupa campuran tanah dan kompos dengan perbandingan $1: 1$. Tanaman tomat sebelumnya telah melalui tahap persemaian pada seed tray ukuran kecil selama 4 minggu dengan media tanam coco peat dan arang sekam dengan perbandingan $1: 1$. Setiap dua buah polybag diletakan pada baki yang berisi air pupuk sebagai persediaan air dan pupuk untuk menunjang pertumbuhan tanaman tomat. Pengecekan air dan pupuk pada baki dilakukan setiap hari untuk menjaga ketersediaannya bagi tanaman.

Setiap polybag ditanam satu tanaman tomat di tengah - tengah polybag. Jumlah tanaman setiap perlakuan terdiri dari 3 tanaman sehingga keseluruhan tanaman untuk 11 perlakuan berjumlah 11 x $4=44$ tanaman. Pada rumah plastik disediakan ajir berupa tali kasur yang digantung pada langit - langit. Ajir yang disediakan 1 hingga 2 tali pertanaman.

Pengamatan dilakukan pada seluruh tanaman dengan komponen pengamatan sebagai berikut:

1. Tinggi tanaman $(\mathrm{cm})$, diukur mulai dari bagian pangkal batang hingga titik tumbuh tertinggi dengan menggunakan meteran pada umur $6 \mathrm{MST}$.

2. Tinggi tanaman hingga tanda pertama (cm), diukur mulai dari bagian pankal batang hingga tandan bunga pertama dengan menggunakan meteran pada umur 6 MST.

3. Diameter batang, diukur pada bagian pangkal batang dengan menggunakan jangka sorong pada umur $6 \mathrm{MST}$. 
4. Serangan Organisme Pengganggu Tanaman (OPT), diamati secara visual pada setiap tanaman tomat yang terserang hama dan penyakit.

5. Jumlah bunga pertandan, diamati secara visual pada setiap bunga yang tumbuh pada tiga tandan bunga pertama.

6. Jumlah buah pertandan, diamati secara visual pada setiap buah yang terbentuk pada tiga tandan bunga pertama.

Uji Jarak Berganda Duncan (UJGD) pada taraf 5\% dilakukan untuk mengetahui adanya perbedaan kemampuan pertumbuhan setiap tanaman introduksi.

\section{HASIL DAN PEMBAHASAN}

Tinggi tanaman pada tanaman tomat introduksi yang diuji memiliki respon pertumbuhan yang cukup beragam. Data pada Gambar 1 menunjukan bahwa pertumbuhan tanaman tomat 'Black Cherry' menunjukan respon pertumbuhan yang terbaik, dengan tinggi tanaman yang mencapai 186,67 cm. Respon pertumbuhan tinggi tanaman terendah terdapat pada tomat 'Golden Sunrise' (Gambar 2).

Perbedaan tinggi tanaman dipengaruhi oleh faktor genetik dari masing - masing kultivar serta faktor lingkungan yang ikut berperan seperti temperatur, intensitas cahaya, dan ketersediaan air serta unsur hara. Surtinah (2007) menunjukan bahwa semakin tinggi tanaman tomat maka berat buah tomat yang dihasilkan semakin meningkat.

Tandan merupakan tempat melekatnya serangkaian bunga dan tempat bertenggernya buah. Tinggi tandan pertama kali muncul selama pertumbuhan menentukan kecepatan tanaman dalam menuju fase generatif yang ditandai dengan proses pembungaan yaitu dihasilkannya tandan bunga. Perbedaan tinggi tandan pertama dipengaruhi oleh faktor genetik pada setiap kultivar tanaman.

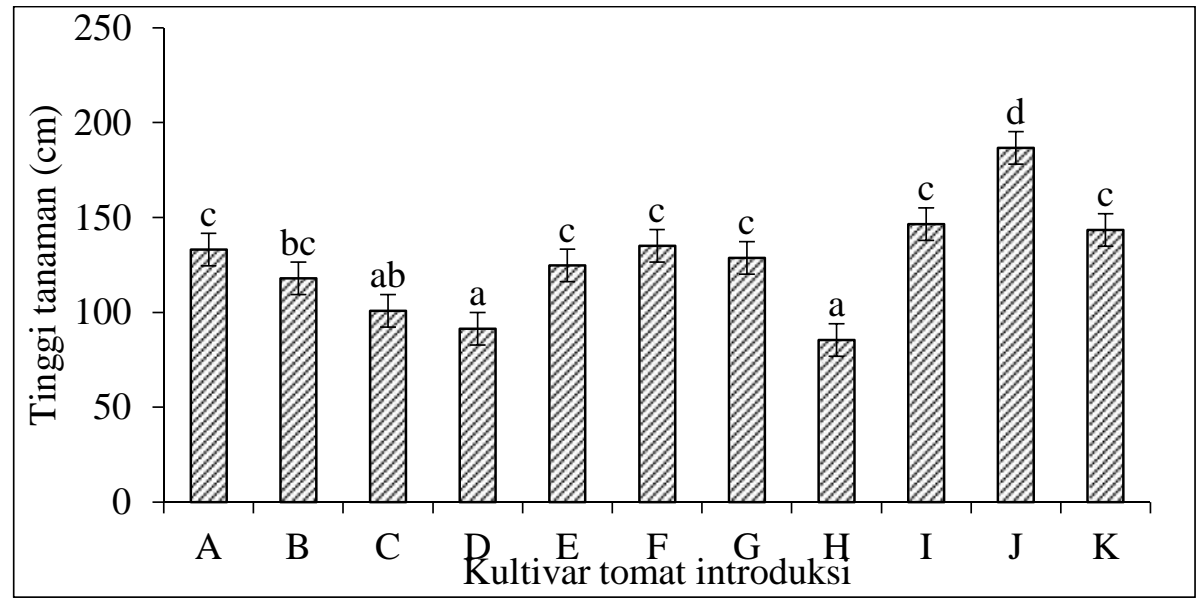

Gambar 1. Tinggi tanaman pada 11 kultivar tanaman tomat introduksi. Nilai rata-rata yang diikuti oleh huruf yang sama pada kolom yang sama tidak berbeda nyata berdasarkan Uji Jarak Ganda Duncan pada taraf 5\%. 


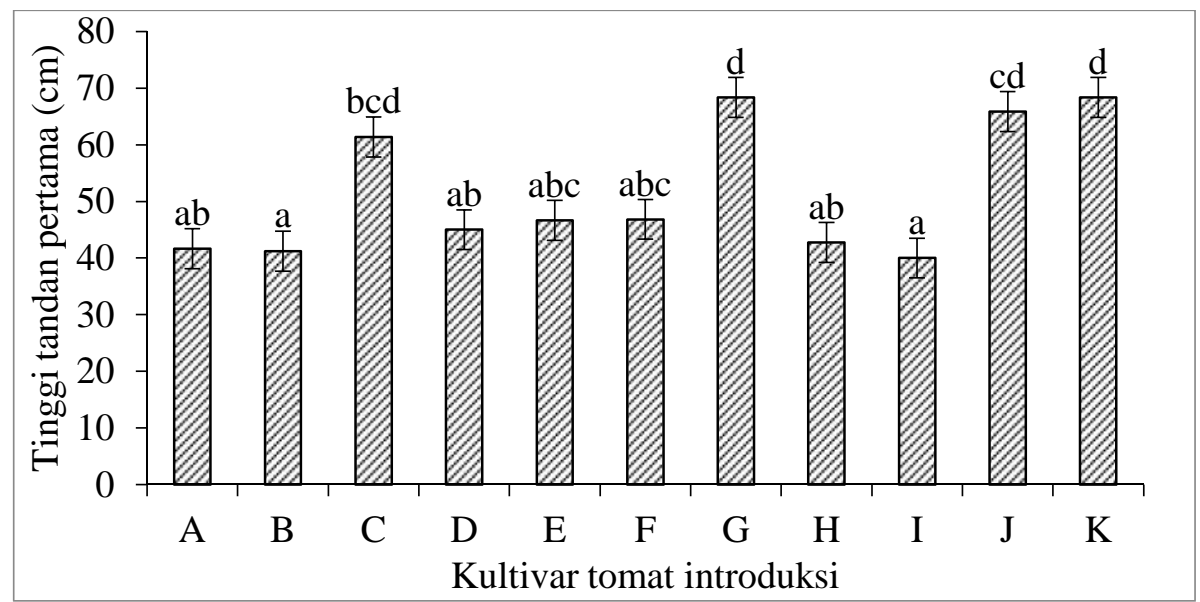

Gambar 2. Tinggi tandan pertama pada 11 kultivar tanaman tomat introduksi. Nilai rata-rata yang diikuti oleh huruf yang sama pada kolom yang sama tidak berbeda nyata pada berdasarkan Uji Jarak Ganda Duncan pada taraf 5\%.

Gambar 2 menunjukan bahwa tomat

'Red Cherry' memiliki tinggi tandan pertama yang terendah $(40 \mathrm{~cm})$ tidak berbeda nyata dengan tomat 'moskvich' (41,23 cm). Respon pertumbuhan tinggi tandan pertama yang tertinggi terdapat pada tomat 'Principle Borghese' dan 'Golden Jubille' dengan tinggi tandan pertama adalah 68,33 cm. Tinggi tandan pertama pada kedua kultivar tersebut secara statistik tidak berbeda nyata dengan yang diperoleh pada tomat 'Black Cherry' dan 'Valensia' yang tingginya mencapai $65,83 \mathrm{~cm}$ dan $61,33 \mathrm{~cm}$.

Diameter batang diukur pada bagian pangkal batang tanaman. Ukuran diameter batang menunjukan tingkat pertumbuhan tanaman yang dipengaruhi oleh ketersediaan unsur hara, hormon, serta faktor genetik. Semakin besar ukuran diameter batang maka produktivitas tanaman tomat akan meningkat baik pada bobot, ukuran, dan jumlah buah tomat yang dihasilkan (Liptay et al., 1981). Hasil penelitian data analisis menggunakan Uji Duncan pada taraf 5\% menunjukkan bahwa ukuran diameter batanag bervariasi antar kultivar tomat introduksi. Diameter batang terbesar diperoleh dari tomat 'Principle Borghese' dengan ukuran diameter batang adalah $13 \mathrm{~mm}$ tidak berbeda dengan tomat 'Oxheart', 'Red Cherry',dan 'Black Cherry' dengan diameter batang masing-masing adalah 11,00 mm, 10,67 mm, dan 11,50 mm. Respon pertumbuhan diameter batang terkecil diperoleh tomat 'Valencia' dengan ukuran diameter $8.67 \mathrm{~cm}$ (Gambar 3).

Jumlah bunga per tandan dan jumlah bunga per tandan dipergunakan sebagai indikator penentu hasil panen. Hasil penelitian menunjukan bahwa terdapat perbedaan yang nyata antara beberapa kultivar tomat introduksi terhadap jumlah bunga yang dihasilkan dalam satu tandan. 


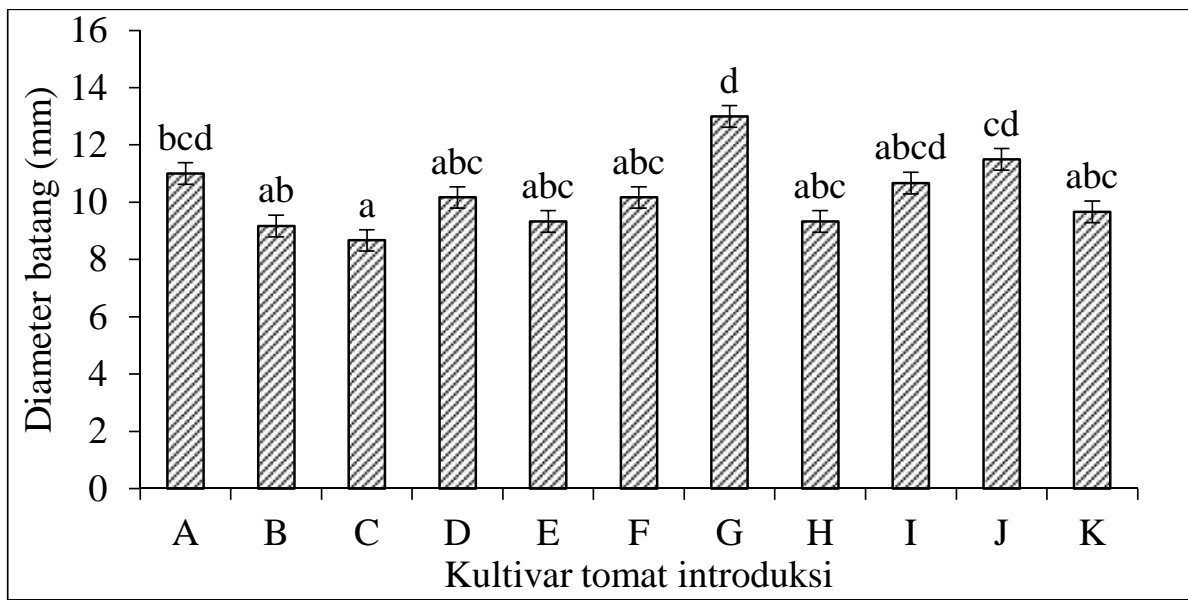

Gambar 3. Diameter batang tanaman pada 11 kultivar tanaman tomat introduksi. Nilai rata-rata yang diikuti oleh huruf yang sama pada kolom yang sama tidak berbeda nyata berdasarkan Uji Jarak Ganda Duncan pada taraf 5\%.

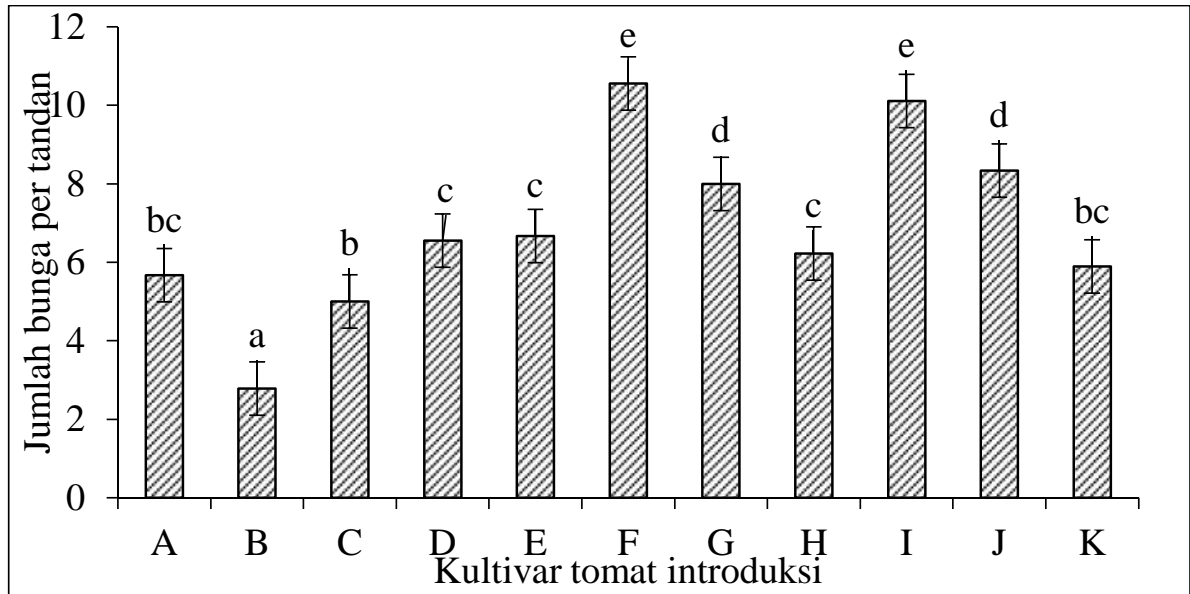

Gambar 4. Jumlah bunga per tandan pada 11 kultivar tanaman tomat introduksi. Nilai rata-rata yang diikuti oleh huruf yang sama pada kolom yang sama tidak berbeda nyata berdasarkan Uji Jarak Ganda Duncan pada taraf 5\%.

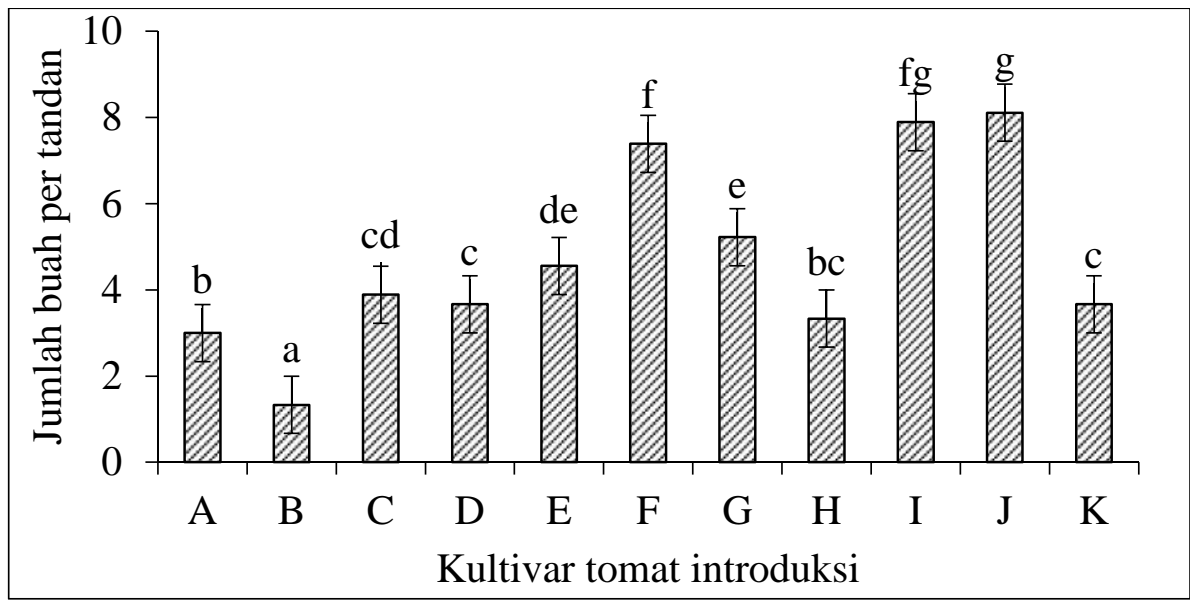

Gambar 5. Jumlah buah per tandan pada 11 kultivar tanaman tomat introduksi. Nilai rata-rata yang diikuti oleh huruf yang sama pada kolom yang sama tidak berbeda nyata berdasarkan Uji Jarak Ganda Duncan pada taraf 5\%. 
Kultivar tomat 'La Sweeti' menunjukan respon pembentukan bunga pertandan lebih banyak dibandingkan kultivar lainnya dengan jumlah bunga 13,44 per tandan tidak berbeda dengan 'Red Cherry' dengan jumlah bunga per tandan sebanyak 10,11. Jumlah bunga pertandan yang paling sedikit ditunjukan oleh kultivar 'Moskovich' dengan rata-rata jumlah bunga pertandan adalah 2.78 (Gambar 4). Pembentukan buah menunjukan berhasilnya proses pembuahan (fertilisasi) yang terjadi pada tanaman tomat tersebut. Berdasarkan data pada Gambar 5, menunjukkan bahwa jumlah buah yang dihasilkan dalam satu tandan menunjukan respon yang beragam. Kultivar tanaman tomat yang menghasilkan buah terbanyak adalah 'Black Cherry' sebanyak 8,11 buah tidak berbeda dengan kultivar 'Red Cherry' yang menghasilkan buah per tandan sebanyak 7,89 buah. Sedangkan jumlah buah yang paling sedikit ditampilkan oleh kultivar 'Moskovich' (Gambar 5). Perbedaan jumlah bunga dan buah yang dihasilkan dalam satu tandan pada setiap kultivar dipengaruhi oleh adanya interaksi antara faktor genetik dan faktor lingkungan. Karakter - karakter akan terus mendapatkan tanggapan dan penyesuaian terhadap lingkungan di sekitar penanaman sehingga dapat terjadi perbedaan antara tanaman satu dan yang lainnya (Suryadi dan Permadi, 1998; Nazirwan, $d k k .$, 2014).
Berdasarkan hasil pengamatan visual terhadap tanaman tomat introduksi menunjukan adanya ketahanan yang beragam terhadap berbagai jenis OPT. Tanaman tomat introduksi mengalami gangguan berupa blossom \& root, penggorok daun, penggerek batang, virus, cendawan, ulat buah, kutu kepul, lalat buah, dan gangguan abiotik berupa kepanasan. Pada tomat introduksi tipe Beef Tomato seperti lebih rentan terhadap serangan ulat buah, lalat buah, dan blossom and root. Penyebab terjadinya blossom and root adalah disebabkan karena kekurangan unsur kalsium pada tanaman tomat serta disebabkan karena adanya fluktuasi pasokan air pada tanaman (Onggo $d k k$., 2015). Ulat buah yang menyerang buah berjenis Helicoverpa armigera. Kekurangan unsur Ca sebagai pembentuk kulit buah disebabkan karena pemberian air yang terlalu tinggi menyebabkan akar muda mati dan tidak tumbuh sehingga unsur $\mathrm{Ca}$ tidak dapat terserap, akibatnya terjadi penguapan yang tinggi pada ujung buah yang kemudian terjadi pengerutan dan pencoklatan. (Kemble et al., 2013; Onggo $d k k ., 2015)$. Penyebab terjadinya blossom and root pada tipe beef tomato saja diduga dikarenakan kebutuhan akan unsur Ca pada tipe beef tomato lebih tinggi dibanding tipe cherry. Ditemukan penyakit layu fusarium yang disebabkan oleh Fusarium oxysporum Schlechtend. f.sp. lycopersici pada tanaman 
tomat kultivar Golden Sunrise. Gejala yang ditimbulkan adalah tinggi tanaman yang kerdil, tanaman layu, dan daun mengecil serta mengerut. Gejala tersebut ditunjukan serupa pada penelitian Ambar dkk. (2010) yang terjadi pada varietas Money Maker dengan isolat yang berasal dari Menggala (Jawa Tengah).

\section{KESIMPULAN}

Tomat introduksi 'Black Cherry' menunjukan respon pertumbuhan yang terbaik pada komponen tinggi tanaman dan jumlah buah yang dihasilkan dalam satu tandan.

\section{DAFTAR PUSTAKA}

Acquaah, G. 2007. Principles of Plant Genetics and Breeding. Blackwell Publ, USA.

Ambar, A. A., A. Priyatmojo, B. Hadisutrisni, dan N. Pusposendjojo. 2010. Virulensi 9 isolat Fusarium Oxysporum F.Sp. Lycopersici dan perkembangan gejala layu Fusarium pada dua varietas tomat di rumah kaca. Jurnal Agrin, 14(2): 89 - 96.

Bhowmilk, D., S. Kumar, S. Paswan, and S. Srivastava. 2012. Tomato-a natural medicine and its health benefits. Journal of Pharmacognosy and Phytochemistry, 1(1): 34 - 39.

BPS dan Dirjen Horti. 2016. Produksi Tomat di Indonesia, 2013-2015. https://www.bps.go.id/site/resultTab. Diakses 25 Desember 2016.

Liptay, A., C. A. Jaworski, and S. C. Phatak. 1981. Effect of tomato transplant stem diameter and ethephon treatment on tomato yield, frtiit size and number. Canadian Journal of Plant Science, 61(2): 413-415.

Marliah, A., M. Hayati, dan I. Muliansyah. 2012. Pemanfaatan pupuk cair organik terhadap pertumbuhan dan hasil beberapa varietas tomat (Lycopersicum esculentum L.) Jurnal Agrista, 16(3): 122-128.

Mubarok, S., Y. Okabe, N. Fukuda, T. Ariizumi, and H. Ezura. 2016. Favourable effect of a weak ethylene receptor mutation Sletrl-2 on postharvest fruit quality changes in tomatoes. Postharvest Biol. Technol Journal, 120(3): 1-9.

Wahyono, Soetjipto, Harjanto, dan Suhariningsih. 2011. Efek jus buah tomat (Lycopersicum pyriforme) terhadap pencegahan fotoaging kulit akibat iradiasi sinar ultraviolet-B. Jurnal Biosains Pascasarjana, 13(3): 169-178

Nazirwan, A. Wahyudi, dan Dulbarin. 2014. Karakterisasi koleksi plasma nutfah tomat lokal dan introduksi. Jurnal Penelitian Pertanian Terapan, 14 (1):70-75.

Onggo, T.M., Sumadi, dan R. Fauziah. 2015. Pertumbuhan, hasil dan kualitas tomat cv. Marta-9 pada berbagai sistem budidaya dalam rumah plastik di dataran medium Jatinangor. Jurnal Kultivasi , 14 (1) : 37 - 42.

Surtinah. 2007. Kajian tentang hubungan pertumbuhan vegetatif dengan produksi tanaman tomat (Lycopersicum esculentum, Mill). Jurnal Ilmiah Pertanian, 4(1): 1-9.

Wijayani, A. dan W, Widodo. 2005. Usaha meningkatkan kualitas beberapa varietas tomat dengan sistem budidaya hidroponik. Jurnal Ilmu Pertanian, 12(1): 77-83. 